\title{
Socio-Economic Instance of Ethnic Group in Bangladesh: A Case Study of Dhaka City
}

\author{
Tahrima Haque Beg \\ Lecturer \\ Department of Management and Finance \\ Sher-e-Bangla Agricultural University, Dhaka, Bangladesh \\ E-mail: tahrima.beg.fin@sau.edu.bd \\ Sunjida Khan \\ Senior Lecturer \\ Department of Business Administration \\ Daffodil International University, Dhaka, Bangladesh \\ E-mail: sunjida.bba@diu.edu.bd \\ Taskin Afrina \\ Lecturer \\ Department of Management and Finance \\ Sher-e-Bangla Agricultural University, Dhaka, Bangladesh \\ E-mail: taskin_mgt@sau.edu.bd \\ Md Shakib Hossain \\ Senior Lecturer \\ Department of Business Administration \\ East West University, Dhaka, Bangladesh \\ E-mail: shakibbhossain@gmail.com

\section{Nurul Mohammad Zayed \\ Assistant Professor \& Head} \\ Department of Real Estate \\ Daffodil International University, Dhaka, Bangladesh \\ E-mail: zayed.bba@daffodilvarsity.edu.bd
}

Received: July I7, 2020

doi: 10.4628I/ijafr.v5i2.743
Accepted: July 30, 2020

Online Published: September 02, 2020

URL: https://doi.org/I0.4628I/ijafr.v5i2.743

\begin{abstract}
In Bangladesh, an ethnic community such as barber, cobbler, washerman, porter become victims of severe discrimination despite the constitutional declaration that protects citizen's equal rights regardless of their race, caste, religion. This study focuses on various minor and untouchable groups in our society. Due to various reasons like lack of education, extreme poverty, lack of proper healthy atmosphere, etc. they could not organize themselves to establish their rights. Consequently, they remain in the darkness of the community. They also remain out of development efforts, untouchable and downtrodden. A cross-sectional survey was carried out from I2 ${ }^{\text {th }}$ February to $27^{\text {th }}$ February 2020 in different areas in the capital city. The purpose of the study is to determine the lifestyle, family background, education level, and socioeconomic impact to access credit among these groups of people.
\end{abstract}

Keywords: Ethnic, Credit, Bank-loan, Socio-Economic Situation, Income, Banking Practice. 


\section{Introduction}

Bangladesh is a land of grueling poverty in terms of economic sense. Diversified Bangladesh, diversified castes-customs had been generated diversified folk-occupational structure. So, our society is experiencing various socio-economic-cultural-behavioralperception-business lives. Through education, scientific innovation improving our life gradually but a part of society is still apart from these improvements. This article highlights such a group of working people who are engaged in shoe polishing or repairing, washing cloth, cutting hair in Dhaka city as well as train/bus station and market corner, depicting the socio-economical dimension with the behavioral approach in their working in comparison with housing life, their perception on the customer and give highlights on problems and suggestive measures with changing society especially these communities. The study aims to find out the livelihood challenges of these minor groups of people and their socio-economic impact on our society as well.

This specific cluster living in poverty with economic deprivation from the beginning of their history and could not put much effort to overcome this drawback. In this survey, we also found that they had not any knowledge about the public or private banking system. No one had any bank account and only $2 \%$ of them saved their money in 'somite'.

\section{Literature Review}

In Bangladesh, the situation of this community is much hopeless. According to Saha and Paul (2003), no one comes forward to take initiative to improve their fate, after in 1947, participation period or 1972, liberation period. Therefore, no example had been found from the administrative

We are moving to know geography, but we are not giving the importance of the Geography of Backward classes' people of society (Akil and Sharma, 1977). A cobbler has to bear the brunt of the scorching sun and wait for customers from early morning until night to earn his livelihood. A study by Uddin (2015) reveals that in Bangladesh the majority possesses family socioeconomic status which is double compared to the minority ethnic groups adding that they are disadvantaged psychologically, socially, and politically along with discrimination, and disproportionate allocation of resources conserves which contributes in creating a disparity in the socioeconomic status between the majority and minority ethnic groups in Bangladesh.

Toppo, Rahman, Ali, and Javed (2016) studied that it is found, majority of the tribal people are participating in agricultural day labor activities while some rely on their cultivable land for production, various formal and non-formal service sectors, in livestock rearing and small business activities like Petty shop, tea stall; out of which Mahali and Roabidas tribal community cling to their traditional professions. But amidst them, the majority of the people earn less than U\$ 50 a month and very few earn more than U\$ 75 a month. Whereas, Pal, Mazumder, Akter, Khatun, and Alam (2017) utilized a self-developed Socio-Economic Index in their research to unravel that ethnic group of Manipuri $(73.17 \%)$ and Khasia $(6.45 \%)$ were having a satisfactory socio-economic status. Chakma and Maitrot (2016) stated after their research that the power dynamics rudimentary to the relationships between the ethnical communities and Bengalees goes overlooked which requires immediate attention by the developing agencies which can be backed by Zuccotti and O'Reilly (2018) remarking that a negligible amount of focus is provided to propagate a cohesive conception of the correspondence between ethnicity, gender and parental employment status which is influencing their youth's education and career outcomes.

Analysis by Darlington, Norman, Ballas, and Exeter (2015) unfolds that while a dissimilarity by health issues are detected, the ethnic incongruity in health is deeply rooted in socioeconomic differences. This can be comprehended in the present context when in their research Martin, Jenkins, Minhas, Gray, Tang, Williams, and Knapp (2020) demonstrated that aggregated documentation reflects, ethnic minority groups are being largely affected by COVID-I9 having an increased likelihood of SARS-CoV-2 PCR positivity.

\section{Research Objectives}

The key objective of the study is to focus on the socio-economic profile of the ethnic communities of the Dhaka city and tried to identify the challenges they faced regularly and develop some suggestions to improve their economic situation. For this, the study has focused on the following issues:

- To point out the factors that influence the socio-economic conditions of these urban marginals or grassroots people in our society.

- To determine the challenges which have been experienced.

- To advocate some recommendations for enhancing their socio-economic conditions.

\section{Research Methodology}

A cross-sectional study was carried out from $12^{\text {th }}$ February to $27^{\text {th }}$ February 2020 . For primary level data, a sample survey was conducted among cobblers. The major portion of the ethnic community lives in Purbachal, Rayer Bazar, Jigatola, Dhanmondi, Savar, and Sutrapur located in Dhaka city. Total 300 number of sample aged between 22 to 60 was randomly selected from the areas like Wari, Shakuria Bazar, Purbachal and Savar, Sutrapur. Targeted people of different locations were requested to cooperate with us to get an interview. A semi-structured pre-tested questionnaire was formatted to collect information on their socioeconomic status including their age, working hours, daily income, expenditures, daily consumption, associated disease 
pattern, education level, monthly saving, interest to get loans, bank account, banking knowledge, etc. All the collected data were analyzed by using the SPSS v-I6.0 program.

\section{Data Analysis}

This paper represents socio-economic situation and financial saving, loan, banking knowledge, education level of cobblers, barbers, porters, washermen, etc. among Dhaka city. After surveying 300 respondents and comparing various data, we found the following results.

Table I. Level of Income of the respondents:

\begin{tabular}{lllllll}
\hline Level of Income & $\begin{array}{l}2000 \text { to more } \\
\text { than } 3000\end{array}$ & $\begin{array}{l}3000 \text { to more } \\
\text { than } 4000\end{array}$ & $\begin{array}{l}5000 \text { to more } \\
\text { than } 6000\end{array}$ & $\begin{array}{l}6000 \text { to more } \\
\text { than } 7000\end{array}$ & $8000+$ & Total \\
\hline \multirow{3}{*}{ Frequency } & 75 & 89 & 49 & 65 & 22 & 300 \\
& $(25 \%)$ & $(29.7 \%)$ & $(16.3 \%)$ & $(21.7 \%)$ & $(7.3 \%)$ & $(100 \%)$ \\
\hline
\end{tabular}

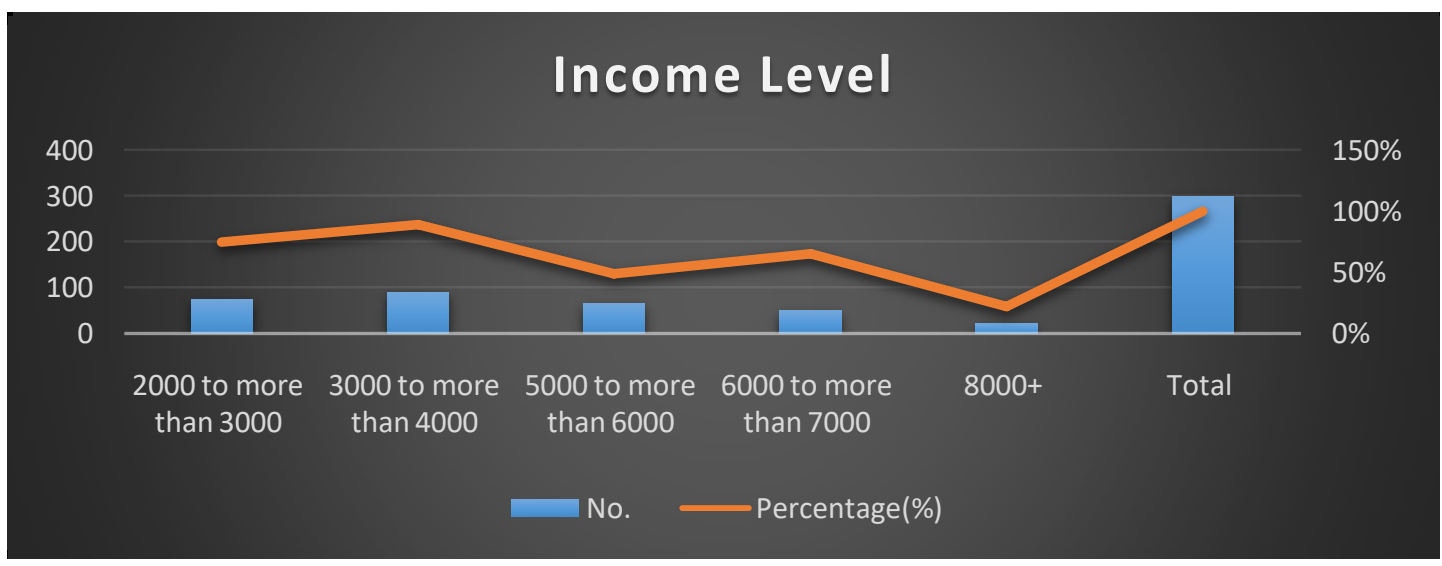

Figure I. Income Level of the Targeted People Source: Estimated

According to Table I, it is found that only $7.3 \%$ of people's income is more than eight thousand, and most (29.7\%) have lied between the range 3000 to 4000 which is too difficult to live in Dhaka city. Moreover, doing this fieldwork, we found that an average of 7 to 8 family members depended only on one or two persons in every family. It is very challenging to maintain their livelihood expenditure at present income.

Table 2. Level of Education of the Respondents

\begin{tabular}{|c|c|c|c|c|c|c|c|}
\hline $\begin{array}{l}\text { Level } \\
\text { Education }\end{array}$ & of & Illiterate & $\mathrm{I}-\mathrm{V}$ & VI-X & SSC+ & $\begin{array}{l}\text { Vocational } \\
\text { Education }\end{array}$ & Total \\
\hline Frequency & & $\begin{array}{l}\text { II } 4 \\
(35 \%)\end{array}$ & $\begin{array}{l}68 \\
(20 \%)\end{array}$ & $\begin{array}{l}43 \\
(\mathrm{II} \%)\end{array}$ & $\begin{array}{l}40 \\
(10 \%)\end{array}$ & $\begin{array}{l}35 \\
(5 \%)\end{array}$ & $\begin{array}{l}300 \\
(100 \%)\end{array}$ \\
\hline
\end{tabular}




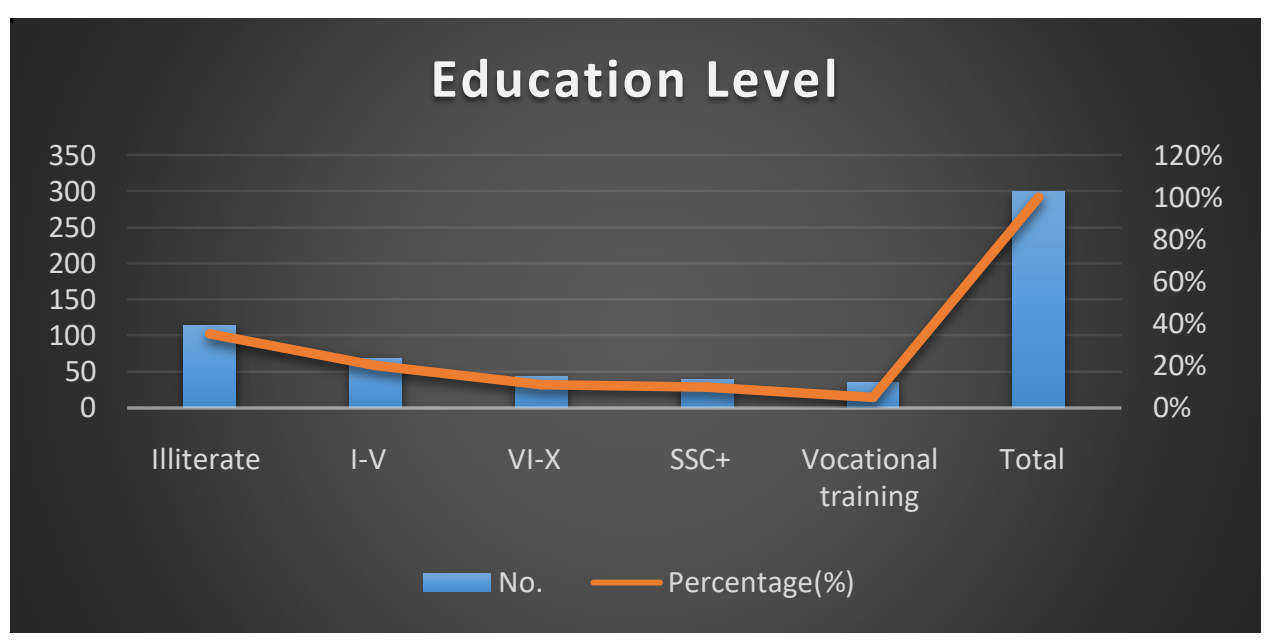

Figure 2. Education Level of the Targeted People Source: Estimated

Table 2 shows the level of education where only $10 \%$ completed their SSC exam. Unfortunately, 35\% of them are illiterate. Moreover, they are not interested in education. Instead of a low level of education, they are not showing much interest in the education of their children today.

Table 3. Ownership of Housing of Respondent Families

\begin{tabular}{llllll}
\hline $\begin{array}{l}\text { Level of } \\
\text { Ownership Pattern }\end{array}$ & Rented & $\begin{array}{l}\text { Own house but built on } \\
\text { other's land }\end{array}$ & & Others & Total \\
\hline & 78 & I & & & \\
Frequency & $(26 \%)$ & $(47 \%)$ & $(14 \%)$ & 39 & 300 \\
& & & $(13 \%)$ & $(100 \%)$ \\
\hline
\end{tabular}

Source: Own Survey, 2020

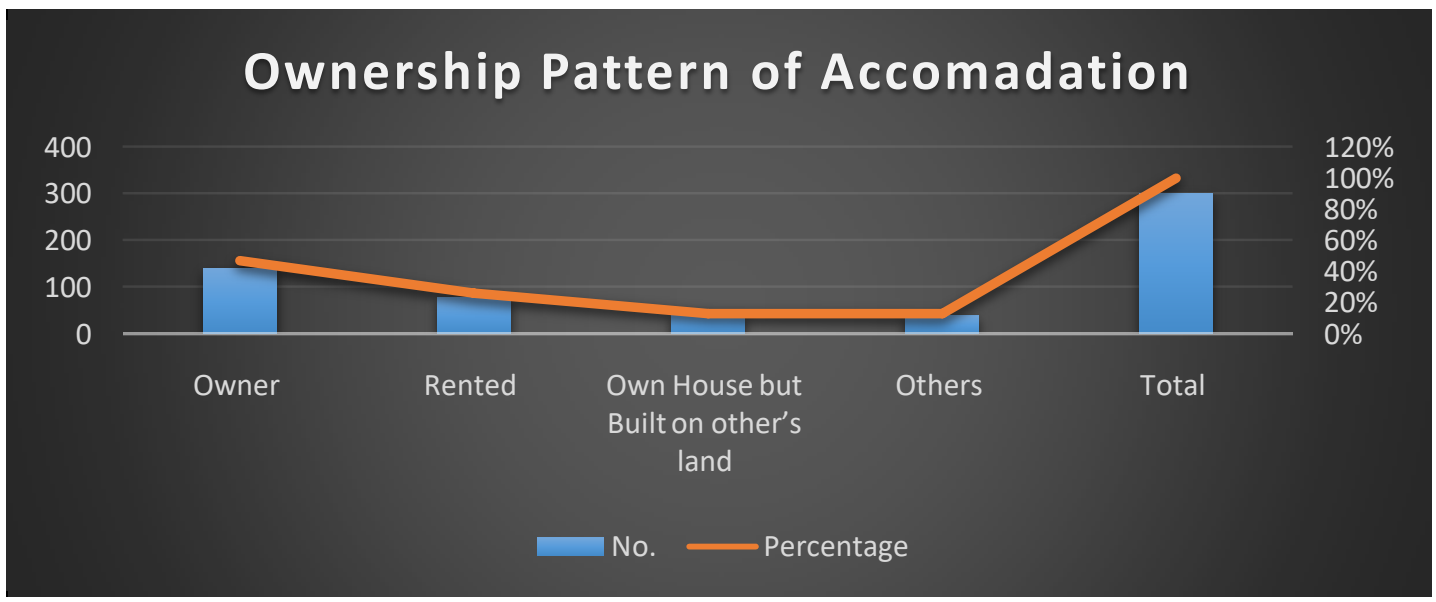

Figure 3. Ownership Pattern of Accommodation

Source: Estimated

Table 3 shows the distribution of ownership of housing of respondent families. According to the table, $26 \%$ are live in their own houses and a very strong significant portion (47\%) of the respondent families lives in rented houses. During the investigation, it is found that they rent in houses within their community. 
Table 4. Source of Drinking water

\begin{tabular}{|c|c|c|c|c|}
\hline $\begin{array}{l}\text { Source of Drinking } \\
\text { Water }\end{array}$ & Tube Well & Direct Piped Water & Others & Total \\
\hline Frequency & $\begin{array}{l}69 \\
(23 \%)\end{array}$ & $\begin{array}{l}180 \\
(60 \%)\end{array}$ & $\begin{array}{l}51 \\
(17 \%)\end{array}$ & $\begin{array}{l}300 \\
(100 \%)\end{array}$ \\
\hline
\end{tabular}

Source: Own Survey, 2020

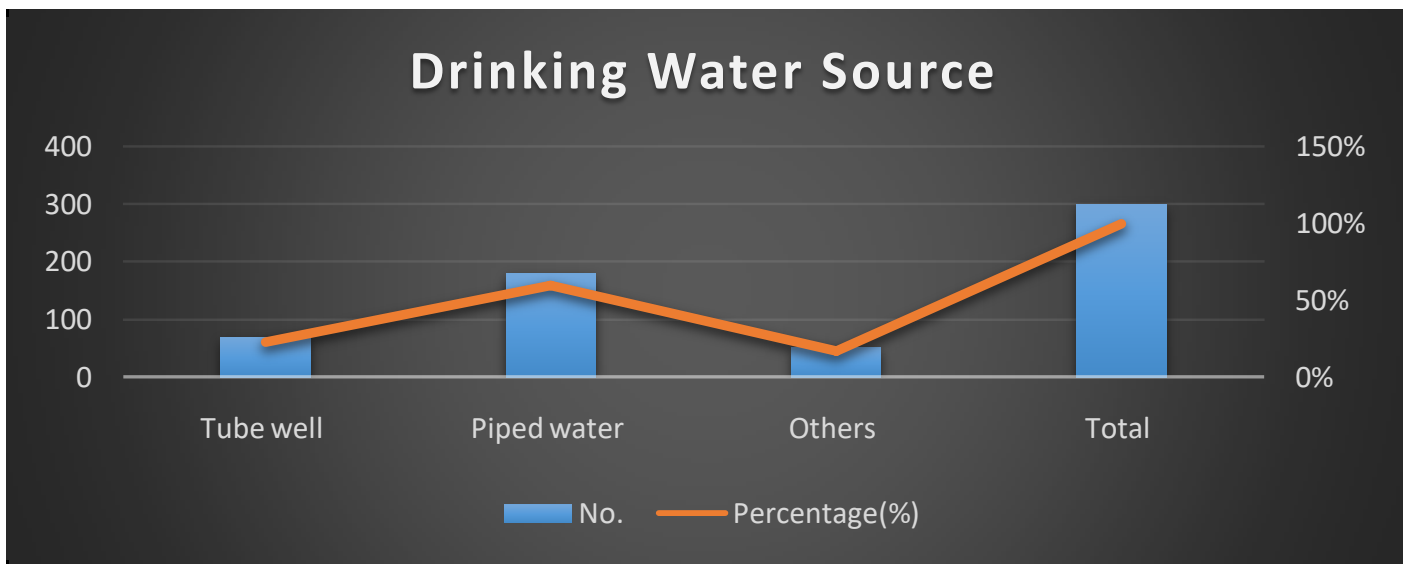

Figure 4. Source of Drinking Water

Source: Estimated

As the target group lives in the urban area majority of the respondents have access to urban utility services, such as supplied water, electricity, etc. Table 4 shows that $60 \%$ respondent families have access to piped water and they drink it directly without any purification.

Table 5. Access to Electricity

\begin{tabular}{|c|c|c|c|c|}
\hline $\begin{array}{l}\text { Source of } \\
\text { Water }\end{array}$ & Drinking & Yes & No & Total \\
\hline Frequency & & $\begin{array}{l}182 \\
(60.7 \%)\end{array}$ & $\begin{array}{l}\text { I I8 } \\
(39.3 \%)\end{array}$ & $\begin{array}{l}300 \\
(100 \%)\end{array}$ \\
\hline
\end{tabular}

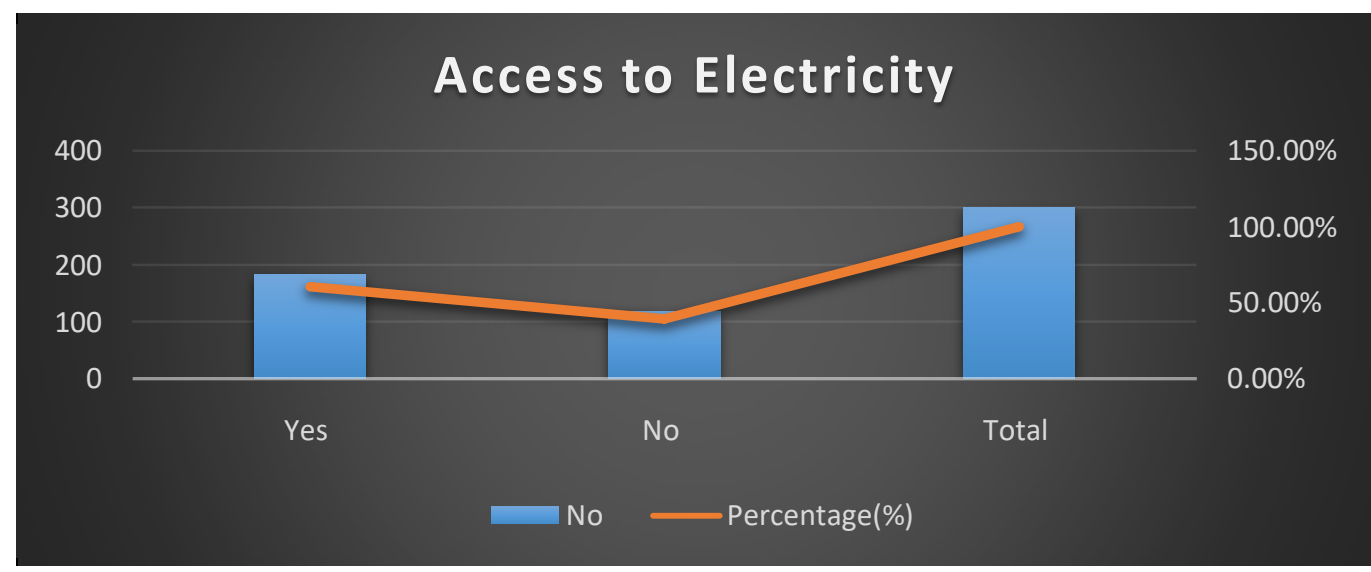

Figure 5. Access to Electricity

Source: Estimated 
From Table 5, it is found that 39.3\% of respondent families have no access to electricity. Sometimes. They used other electrical connections illegally. From these tables, we can easily understand the difficulties and hardships of the lifestyle of this untouchable and minor group of people.

Table 6. Infected Incidence of Illness (in various diseases)

\begin{tabular}{lllllllll}
\hline $\begin{array}{l}\text { Source of } \\
\text { Drinking } \\
\text { Water }\end{array}$ & Fever/influenza & Diarrhea & Gastric/Ulcer & Malnutrition & $\begin{array}{l}\text { Skin } \\
\text { disease }\end{array}$ & Dengue & Pneumonia & Total \\
\hline \multirow{3}{*}{ Frequency } & 93 & $(3 \mathrm{I} \%)$ & 75 & $\mathrm{I} 8$ & 45 & $\mathrm{I} 2$ & 45 & $\mathrm{I} 2$ \\
\end{tabular}

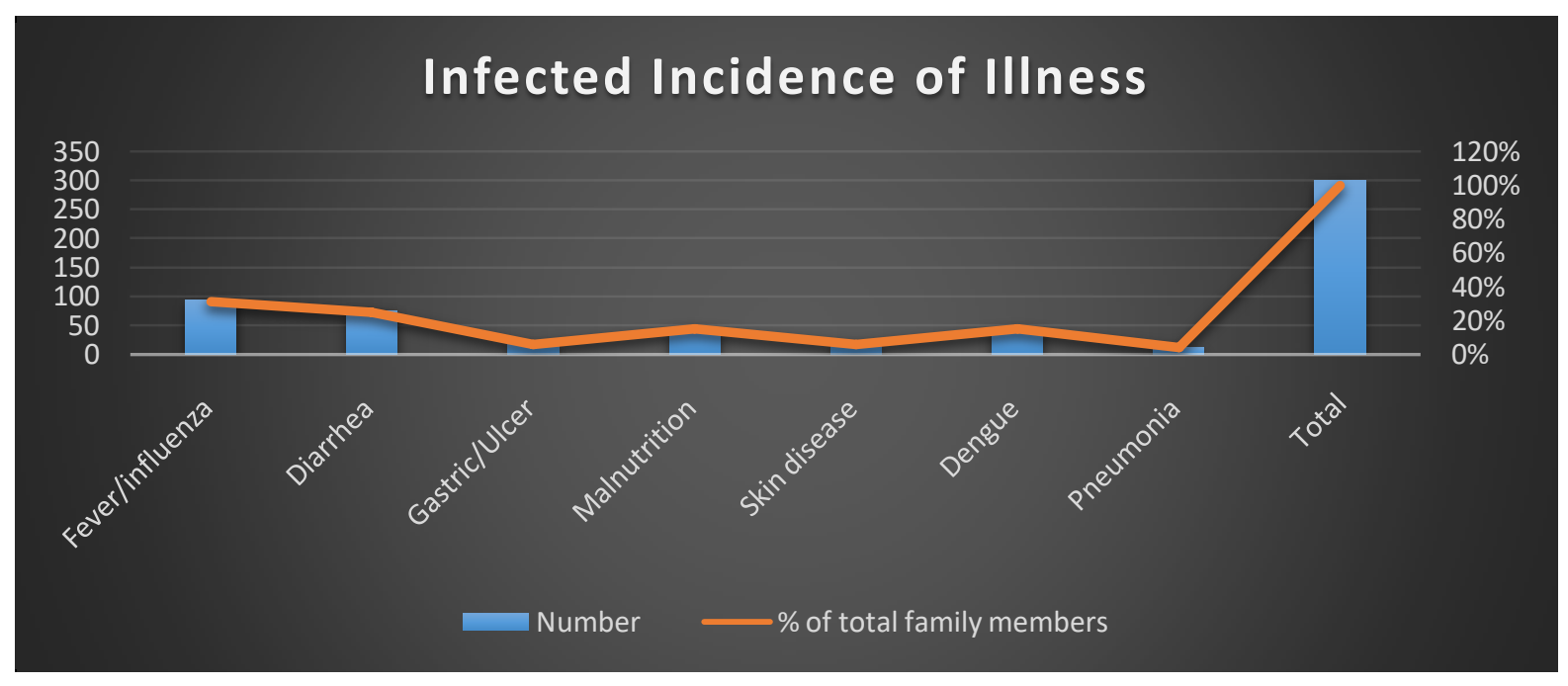

Figure 6. Infected Incidence of Illness(in various diseases)

According to Table 6, because of the unhygienic condition and extreme poverty, this minor group of people also were suffered from different diseases, such as fever, (influenza), diarrhea, gastric ulcer, malnutrition, etc. Again, in this field survey, we found that they had less knowledge about a healthy lifestyle and medical support

Table 7. Decision Maker of Family in the following

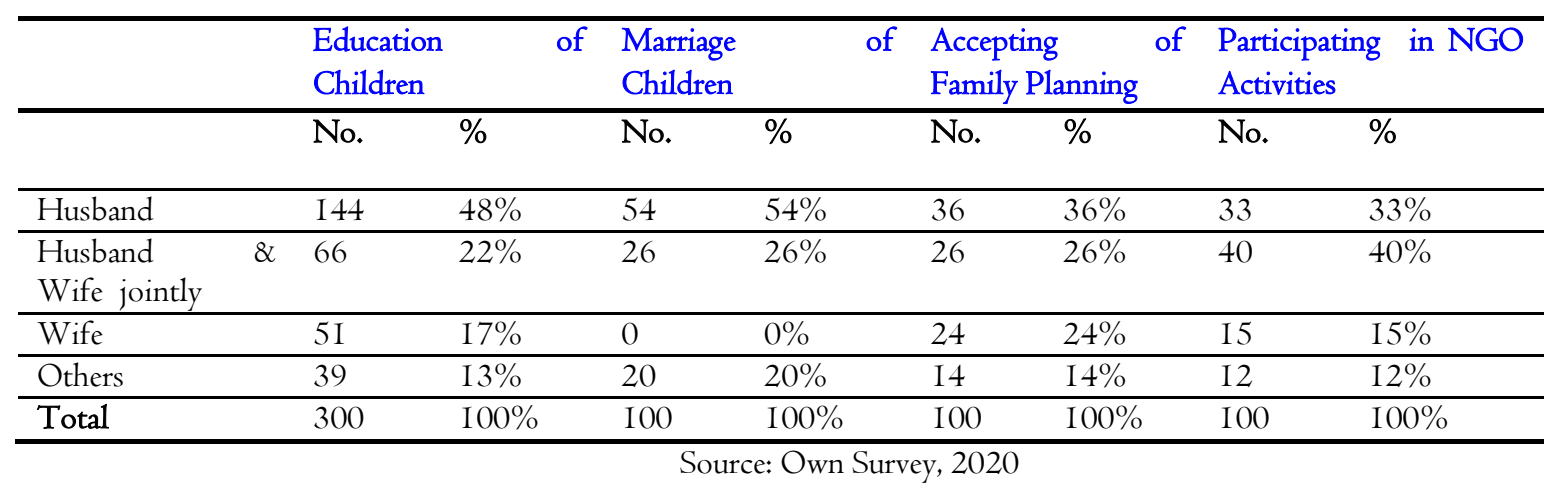




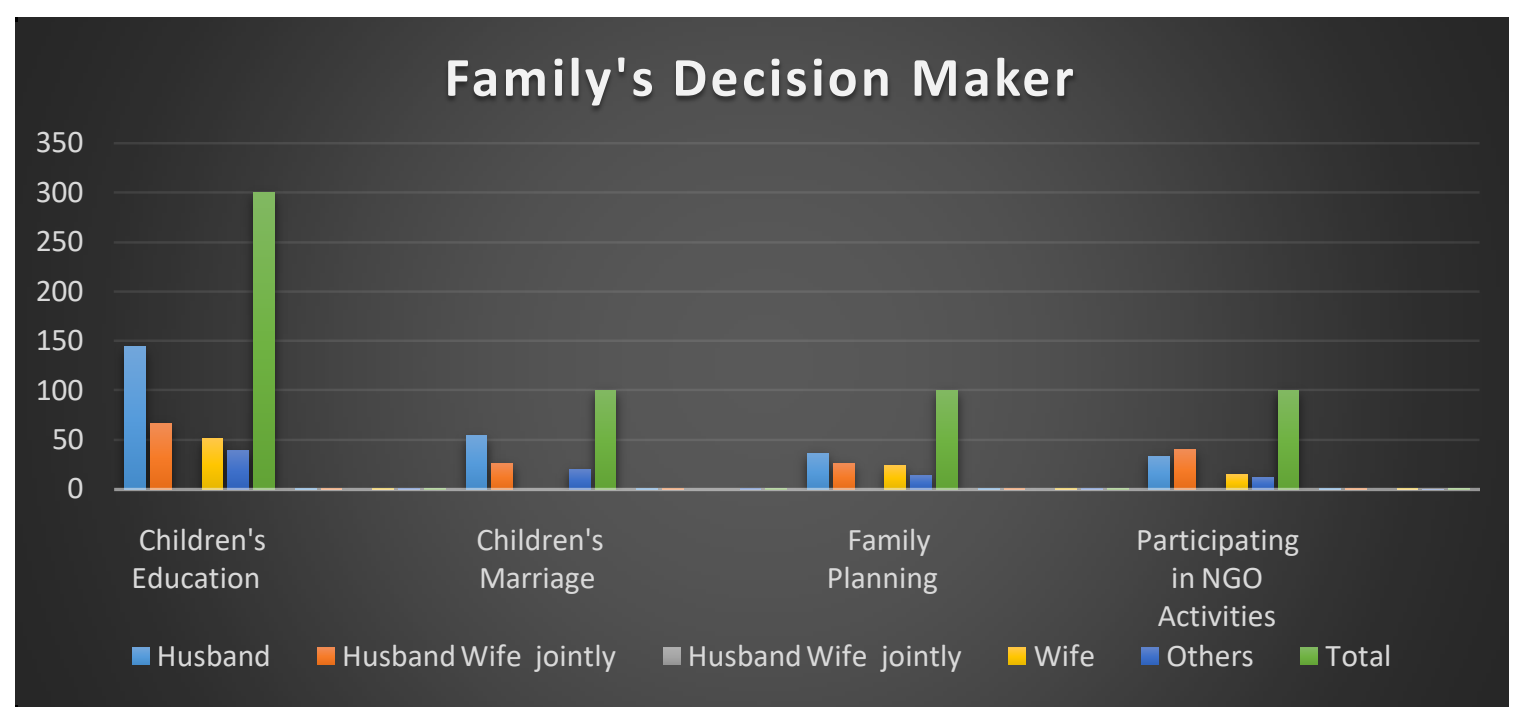

Figure 7. Decision Maker of Family

\section{Source: Estimated}

Table-7 shows that most of the decisions were taken by the men. We found that women engaged in a variety of economic activities ranging from home-based expenditure saving activities to outside paid activities, much of it are not socially valued as 'work'. Table 7 also indicates that decisions on education and marriage of the children of the respondent families are being taken by husbands.

\section{Findings of the Research \\ 6.I Socio-Economic Status \\ 6.I.I Family Type}

Commonly, every family of the group has only one earner and he dominates the whole family as well. Each family consists of 5 to 6 people on average members and they bear their food, accommodation, medical, education, etc. all expense. So, every single step they face poverty and live with poverty. Women are involved with taking care of their children and all household activities such as cooking, washing, cleaning, and so on. Join family culture is very rare for their urban family life.

\subsubsection{Religion}

There is no diversified religious of this cluster expect Hindu. Traditionally they belong to the Hindu religion. However, it's a period of globalization, and all people from all regions' considered equal in the society, but still this statute untouched for the minor cluster.

\section{I.3 Political Life}

Politics can not affect their life sharply. They are always far away from any political thinking as well as a political party. Their main objective to live life is to survive against all hazards. Therefore, as a citizen, they only cast their vote without considering whether the political candid qualified or not.

\subsection{Educational Status}

Poor economic status and higher cost of education lead to creating less interest in education and demotivated them from education. It is very rare to find their wife or female members of their family being educated. Based on their financial status, they decide whether their children will enroll and continue their education or not.

\subsection{In House Environment}

House ownership pattern is very usual of this cluster. They live in other's people houses or rental houses. Lack of electricity, the inability of a separate kitchen, inability to separate washroom, lack of water, lack of gas are the common features of their housing facilities. They stay in a very unhygienic environment with a large family size and it makes the houses congested and polluted. In house ventilation system of their house is very weak due to the narrow space room and thus, various diseases spread up among them very rapidly and infected the rest of the people quickly. 


\subsubsection{Access to Water and Sanitation}

They are not concern about drinking pure and safe water. Deep filtration tube well, filter, purify machine, etc. are absent in their house. Direct supply water, open well, river, ponds beside the road, etc. are the source of their water and they used to drink, and other household activities by this water. In consequence, they are easily infected by various water-borne diseases. The same feature is found for sanitation. One toilet is used by many people. Dirtiness and bad smell are the common phenomena of their toilet. The drainage system is also very weak and poor.

\subsubsection{Cleanness and Consciousness}

They wear the same cloth repeatedly from morning to night while completing their tasks. They are not habituated with the use of soap regularly. Therefore, most of the cases, they are not properly sanitized by washing hands before eat and after the toilet. Moreover, they do not use mosquito nets during sleeping. Buying soap, mosquito net, etc. are treated as an extra expense to them. They become poor personal hygienic being due to dirty cloth, dirty hands, lack of awareness, and conscious about health and suffer various daises all over the year.

\subsubsection{Smokey and Drinking Life}

Smoking is a common feature of them. The access to smoke specially Biri in front of their family members and are not concern about the hazardous effect of smoking on their child. After completing their work most of them are addicted to local alcohol daily before going to the house at night.

\section{Conclusion \& Recommendations}

Despite being Bangladeshi citizens, these minor and untouchable groups in the society victims of various social disparities and inequalities. In our constitution, their rights are not truly reflected and they deprive of their actual privileges. They could not appear as a strong and powerful cluster due to various pitfalls, such as proper educational opportunities, proper owning property, poor economic status, and socio-economic drawbacks. No initiatives or actions have been taken to improve their socio-economic and livelihood status by the Government and assigned authorities. Thus, they remain poor with good craftsmanship over the centuries. Specific programs and actions should be taken by the Government to change their socio-economic situation, a healthy and hygienic atmosphere should be ensured. Besides these, creating access to finance for this untouchable and minor group must be needed. However, the Government and authority could take such initiative in which they will get all facilities to live their livelihood under one umbrella, live become meaningful and magnificent to them.

\section{References}

Akil, G. \& Sharma, A. (1977). The Anthropology of the State.

Chakma, N., \& Maitrot, M. (2016). How ethnic minorities became poor and stay poor in Bangladesh: A qualitative enquiry. EEP/Shiree, July.

Darlington, F., Norman, P., Ballas, D., \& Exeter, D. J. (2015). Exploring ethnic inequalities in health: evidence from the Health Survey for England, I998-20I I. Diversity and Equality in Health and Care, I2(2), 54-65.

Martin, C. A., Jenkins, D. R., Minhas, J. S., Gray, L. J., Tang, J., Williams, C., ... \& Knapp, S. (2020). Socio-demographic heterogeneity in the prevalence of COVID-I9 during lockdown is associated with ethnicity and household size: Results from an observational cohort study. EClinicalMedicine, I00466.

Pal, N., Mazumder, M. S., Akter, S., Khatun, M. A., \& Alam, M. (2017). Socioeconomic status of the ethnic community in Bangladesh: An analysis using socio-economic index. IOSR Journal of Economics and Finance (IOSR-JEF) e-ISSN, 232I-5933.

Saha, P. \& Paul, R.N. (2003). The Socio-Economic Situation of the Cobbler Community (an Untouchable Class of Our Society) in Dhaka City: An Overview

Toppo, A., Rahman, M. R., Ali, M. Y., \& Javed, A. (2016). The socio-economic condition of plain land tribal people in Bangladesh. Social Sciences, 5(4), 58-63.

Uddin, E. (2015). Ethnic disparity in family socioeconomic status in Bangladesh: implication for family welfare policy practice. Global Social Welfare, 2(I), 29-38.

Zuccotti, C. V., \& O’Reilly, J. (20I8). Ethnicity, gender and household effects on becoming NEET: an intersectional analysis. Work, employment and society, 33(3), 35I-373.

\section{Copyrights}

Copyright for this article is retained by the author(s), with first publication rights granted to the journal. This is an open-access article distributed under the terms and conditions of the Creative Commons Attribution license (http://creativecommons.org/licenses/by/4.0/). 